\author{
Monika Juchniewicz \\ Institute of Agricultural and Food Economics - National Research Institute \\ Lukasz Podstawka \\ Warsaw University of Life Sciences
}

\title{
DEVELOPMENT OPPORTUNITIES OF POLISH FARMS
}

The main objective of the study is to identify and evaluate development opportunities among agricultural holdings in Poland according to agricultural types and economic size classes. The study refers to the period between 2015 and 2019 and concerns data regarding farms run by natural persons conducting agricultural accounting within the Polish FADN. The aim of the study was achieved by assessing the level of income from a family farm as well as accumulation and reproduction in the agricultural holdings under consideration. The research shows that there was a differentiation in the development potential of farms run by natural persons depending on the agricultural type and economic size class. The highest average accumulation in relation to family farm income, as well as the highest reproduction rate, was observed in farms producing poultry. Farms with field crops, horticulture, dairy cows and pigs also had more accumulation than depreciation and these farms provided an extended reproduction of fixed assets. On the other hand, in holdings with mixed crop and animal production, with permanent crops and specialised in grassland animal husbandry, there was a narrower reproduction of fixed assets.

The analysis of agricultural holdings run by natural persons showed that the accumulation rate and the reproduction rate increased along with the economic size of agricultural holdings. Farms with an economic size of up to EUR 25 thousand SO in the studied period recorded a negative accumulation rate and reproduction rate. In the group of farms with an economic size of EUR 25 to 50 thousand, the reproduction rate was 1. On the other hand, in the economic size classes above EUR 50 thousand SO there was an extended reproduction.

Key words: depreciation, accumulation, agricultural holding.

JEL Codes: Q12, Q14, D25.

\section{Introduction}

A farm aims to obtain an economic surplus in the form of income, which is one of the fundamental analytical categories in agricultural economics ${ }^{1}$ and is, on the one hand, a determinant of the farm's development opportunities, especially with regard to investments and related accumulation processes ${ }^{2}$; on the other hand, it provides compensation for work and determines the standard of living of farmers and their families. Therefore, an appropriate level of income covers basic social and economic

\footnotetext{
${ }^{1}$ Kryszak Ł., Czyżewski B.: Determinanty dochodów rolniczych. Warszawa: Wydawnictwo CeDeWu, Warszawa 2020, s. 9.

${ }^{2}$ Grzelak A.: Ocena procesów reprodukcji majątku gospodarstw rolnych prowadzacych rachunkowość rolną (FADN), Zagadnienia Ekonomiki Rolnej, 3 (340), Wydawnictwo IERiGŻ-PIB, Warszawa 2014, s. 45-51.
} 
expectations and enables the farmer's family and the farm to develop ${ }^{3}$. A low level or lack of income erodes the basic function of a farm as a place of work, and the family may start to look into other options for the future ${ }^{4}$. Referring to Ryś-Jurek's review of research on farmstead objectives ${ }^{5}$, it can be noted that of particular importance for farmers were, among others, obtaining a satisfactory level of income from the farm that would cover consumption needs and ensure financial resources to invest in the farm. There are complementary and competitive relationships within the income derivatives, that is, consumption and accumulation over time. In the short term, there is a contradiction between these quantities. Accumulation is the resultant quantity after the satisfaction of consumption needs, which is a priority for farmers and their families ${ }^{6}$. In the long term, this contradiction is not so pronounced, as the accumulation process, and thus investments, will influence the level of farm income and, consequently, consumption in the future ${ }^{7}$.

Accumulation is a part of income whose level determines the capability to survive and develop agricultural holdings. Wiatrak ${ }^{8}$ rightly states that "the level of accumulation in a farm indicates the farmer's attitude towards the development of agricultural production in the existing economic conditions and can be used to determine the future development of agriculture", as well as the competitiveness of Polish agricultural holdings on the international market. On the other hand, Józwiak ${ }^{9}$ notes that positive accumulation, investment and enlargement of resources testify to the development possibilities and willingness for further agricultural production.

It is therefore important to monitor the income situation and thus the distribution of income between consumption and accumulation in agricultural holdings. This justifies undertaking research in the above area.

The main objective of the study is to identify development opportunities among farms run by natural persons in 2015-2019. The objective was achieved by assessing the level of income from a family farm as well as accumulation and reproduction in individual agricultural types and economic size classes of such agricultural holdings within the Polish FADN.

${ }^{3}$ Kata R.: Wewnątrzsektorowe nierówności dochodów gospodarstw rolniczych w Polsce w latach 2004-2017, Nierówności społeczne a wzrost gospodarczy, 61, Wydawnictwo Uniwersytetu Rzeszowskiego, Rzeszów 2020, s. 26-27.

4 Poczta W.: Instrumenty wsparcia ekonomicznego dla rodzinnych gospodarstw rolnych w polityce strukturalnej UE i w ramach interwencjonizmu państwowego oraz rola i znaczenie tych instrumentów. W: M. Podstawka (red.), Ekonomiczne i prawne mechanizmy wspierania i ochrony rolnictwa rodzinnego, KSOW Warszawa 2015, s. 142-159.

${ }^{5}$ Ryś-Jurek R.: Zachowanie finansowe gospodarstw rolnych, Handel wewnętrzny, 4 (363), 2016, s. 242-245.

${ }^{6}$ Grzelak A.: Akumulacja majątku w gospodarstwach rolnych w Polsce ze względu na typy produkcyjne i kontekst paradygmatu rozwoju zrównoważonego, Zagadnienia Ekonomiki Rolnej, 3 (360), Wydawnictwo IERiGŻ-PIB, Warszawa 2019, s. 90-91.

${ }^{7}$ Wiatrak A. P.: Współzależność akumulacji i spożycia w gospodarstwach i rodzinach chłopskich, Wieś i rolnictwo, 1 (22), 1979, s. 163.

${ }^{8}$ Wiatrak A. P.: Uwarunkowania akumulacji w gospodarstwach rodzinnych w rolnictwie, Wieś i rolnictwo, 4 (57), 1987, s. 25.

${ }^{9}$ Józwiak W.: Strategie postępowania posiadaczy gospodarstwach rolnych i ich pozarolnicze formy aktywności gospodarczej w latach 1996-2002, Roczniki Naukowe SERiA, 6 (3), 2004, s. 94-100. 


\section{Research methodology}

In the study, in order to identify development opportunities, data from commodity farms run by natural persons conducting agricultural accounting within the Polish FADN were used. The analysis covers the period of 2015-2019.

For analytical purposes, consumption was defined as the level of minimum subsistence determined by the Institute of Labour and Social Affairs. The value of accumulation was determined as the difference between the income obtained from a family agricultural holding and estimated consumption. Thus, accumulation was treated as a part of income accumulated in order to maintain the continuity of production processes and carry out investments in an agricultural holding.

In order to achieve the set objective, the income from a family agricultural holding, accumulation rate and reproduction rate were characterised. The values of individual parameters are arithmetic averages from the sample of analysed farms. Income from a family farm in the accounting system used by the Polish FADN is a basic category of result and constitutes an economic surplus from the operational activity of an agricultural holding. It reflects compensation for the farmer's family's unpaid labour and for the involvement of their own capital in the operational activity of the agricultural holding ${ }^{10}$.

Accumulation was analysed by means of the accumulation rate, treated as the ratio of the estimated accumulation value to the income from the family farm. Reproduction, in turn, was determined by the reproduction rate defined as the relation of the estimated value of accumulation to the value of depreciation write-offs in a given year.

Following Sobczyński ${ }^{11}$, it was assumed that if the reproduction rate is above 1 , a farm indicates a capacity for expanded reproduction. In the case of a rate equal to 1 , simple reproduction occurred, while $0-<1$ demonstrates narrowed reproduction. On the other hand, with a negative reproduction rate, there is no chance for development or even the possibility to reproduce fixed assets.

The study evaluated the listed economic categories by dividing the farms by agricultural type (TF8): field crops, horticultural crops, permanent crops, dairy cows, grass animals, pigs, poultry, mixed, and by economic size (ES6): very small $(2<=€<$ 8), small $(8<=€<25)$, medium-small $(25<=€<50)$, medium-large $(50<=€<100)$, large $(100<=€<500)$ and very large $(€=>500)$.

Research hypotheses:

1. Accumulation and reproduction are positively correlated with the economic size of farms.

2. Farms specialising in poultry production have the highest development potential.

\section{Findings}

As mentioned in the introduction, the level of income from the family farm is particularly important for farmers and their families, as it indicates remuneration for their own work. Some of this income is allocated to accumulation, being one of the basic

${ }^{10}$ Goraj L., Mańko S.: Rachunkowość i analiza ekonomiczna w indywidualnym gospodarstwie rolnym, Wydawnictwo Difin, Warszawa 2009.

${ }^{11}$ Sobczyński T.: Wpływ wielkości ekonomicznej gospodarstw rolniczych UE na ich możliwości rozwojowe. Zeszyty Naukowe SGGW w Warszawie. Problemy Rolnictwa Światowego, 9 (24), Warszawa 2009, s. 161 162. 
sources of investment in farms, and some to consumption, determining the standard of living enjoyed by farmers and their families.

The analysis of the research material presented in Table 1 shows that the average income from a family farm in the studied group of FADN farms at current prices in the period 2015-2019 oscillated between 74,849 and 99,159 PLN. In terms of income, the situation of farms in the studied period was improving. The exception was the year 2018, when there was a $12 \%$ decrease against 2017; nevertheless, the average income recorded in that year was higher in comparison with 2015, when it was at the lowest in the analysed period. The highest income per family farm was achieved in 2017. The aforementioned year also saw the highest increase in income, by about $24 \%$.

Table 1. Income from family agricultural holding according to current prices, accumulation rate and reproduction rate in the studied group of farms in 2015-2019 (average per 1 farm)

\begin{tabular}{|c|c|c|c|}
\hline Year & $\begin{array}{l}\text { Income from a family farm } \\
\text { in PLN }\end{array}$ & $\begin{array}{l}\text { Accumulation rate } \\
\text { in } \%\end{array}$ & Reproduction rate \\
\hline 2015 & 74,849 & 47.7 & 1.0 \\
\hline 2016 & 80,067 & 50.6 & 1.1 \\
\hline 2017 & 99,159 & 59.1 & 1.6 \\
\hline 2018 & 87,239 & 52.7 & 1.3 \\
\hline 2019 & 95,186 & 55.6 & 1.5 \\
\hline
\end{tabular}

Source: Own study based on FADN data.

Within the studied group of farms, relatively small changes in as regards the relation between accumulation and income from a family farm may be observed. It should be noted, however, that as the agricultural income increases, the level of accumulation rises and vice versa. This indicates that the propensity to accumulate in agricultural holdings run by natural persons is shaped by the amount of income from the family agricultural holding. Farms in the study achieved an accumulation rate ranging from 47.7 in 2015 to $59.1 \%$ in 2017.

The assessment of the development potential of farms based on the assessment of the accumulation rate is an indirect measure. The important issue is to relate the estimated accumulation to annual depreciation allowances, which makes it possible to determine whether farms are able only to reproduce worn-out fixed assets and thus have a chance to function, or whether, in addition to reproducing assets, they have a chance for further development. As Sobczyński ${ }^{12}$ states, a condition for the development of an agricultural holding is not only the replacement of production assets, but also making development investments.

In 2015 , in the case of the reproduction rate in the surveyed farms run by natural persons, accumulation is equal to depreciation. On the other hand, in other years, the farms achieved more accumulation than depreciation in the given period, which indicates

${ }^{12}$ Sobczyński T.: Ocena możliwości rozwojowych gospodarstw rolniczych Unii Europejskiej na podstawie inwestycji netto w latach 1998-2008, Folia Pomeranae Universitatis Technologiae Stetinesis, Oeconomica, 291 (65), 2011, s. 145-156. 
not only the possibility of continued operation, but also the development potential within the group of farms covered by the study.

\section{Agricultural type and development opportunities in agricultural holdings run by natural persons}

The assessment of natural persons' farms in terms of income from a family farm, accumulation rate and reproduction rate was conducted for farms grouped by agricultural type. The analysis carried out within the agricultural types showed that the earned income from a family agricultural holding at current prices in 2015-2019 varied (Table 2) and ranged on average from PLN 48,785 to PLN 325,461. Farms oriented towards rearing grassland animals achieved the lowest income from the family agricultural holding within the period under consideration. The highest income of over PLN 325 thousand was generated by farms producing poultry. In these farms, as well as in farms with horticultural crops, dairy cows, grassland animals, pigs and farms with mixed crop and animal production, significant income growth was recorded between 2019 and 2015. Particularly high income growth per family farm occurred on farms specialising in pig rearing (income growth between 2019 and 2015 was 156\%). Farms with field crops and especially with permanent crops recorded a decrease in income (by 7 and $23 \%$ respectively).

It should be added that the highest income by year for farms with field crops and permanent crops was recorded in 2015. An analogous situation occurred in 2017 among farms specialising in dairy cows, grassland animals and farms with mixed production profile. For other agricultural types of farms, i.e. horticultural crops, pigs and poultry, the highest income was recorded in 2019.

Table 2. Income from a family farm according to current prices divided into agricultural types for the surveyed farms in 2015-2019 (average per 1 farm in PLN)

\begin{tabular}{|c|c|r|r|r|r|r|c|c|}
\hline Year & $\begin{array}{c}\text { Field } \\
\text { crops }\end{array}$ & $\begin{array}{c}\text { Horticultural } \\
\text { crops }\end{array}$ & $\begin{array}{c}\text { Permanent } \\
\text { crops }\end{array}$ & \multicolumn{1}{c}{$\begin{array}{c}\text { Dairy } \\
\text { cows }\end{array}$} & $\begin{array}{c}\text { Grassland } \\
\text { animals }\end{array}$ & Pigs & Poultry & Mixed \\
\hline 2015 & 90,291 & 112,706 & 69,696 & 86,607 & 46,466 & 79,592 & 315,133 & 45,987 \\
\hline 2016 & 82,007 & 101,969 & 40,861 & 99,150 & 46,977 & 135,177 & 280,783 & 56,014 \\
\hline 2017 & 92,530 & 80,736 & 66,420 & 145,152 & 52,224 & 157,763 & 319,177 & 70,247 \\
\hline 2018 & 88,020 & 92,595 & 33,043 & 136,298 & 45,890 & 98,295 & 329,422 & 58,107 \\
\hline 2019 & 84,161 & 117,377 & 53,924 & 139,740 & 51,154 & 204,040 & 390,639 & 67,854 \\
\hline $\begin{array}{l}\text { Average level } \\
\text { during the } \\
\text { period under } \\
\text { consideration }\end{array}$ & 87,308 & 101,056 & 52,831 & 120,469 & 48,785 & 130,476 & 325,461 & 59,158 \\
\hline
\end{tabular}

Source: Own study based on FADN data.

In the group of surveyed agricultural holdings a differentiation was observed in the accumulation rate between agricultural types and years covered by the analysis. The analysis of data presented in Table 3 shows that the highest average accumulation value 
in relation to income from a family agricultural holding, and thus the most proinvestment, were farms specialising in poultry farming. On the other hand, the lowest ability to develop was characterised by farms with permanent crops and those specialising in grassland animal husbandry. The situation in 2018 of farms with permanent crops is worth highlighting. Income on these farms was insufficient to meet consumption needs. Thus, a negative accumulation rate was recorded on these farms.

Table 3. Accumulation rate divided into agricultural types for surveyed farms in 2015-2019 (average per 1 farm in \%)

\begin{tabular}{|c|c|c|c|c|c|c|c|c|}
\hline Year & $\begin{array}{l}\text { Field } \\
\text { crops }\end{array}$ & $\begin{array}{l}\text { Horticultural } \\
\text { crops }\end{array}$ & $\begin{array}{l}\text { Permanent } \\
\text { crops }\end{array}$ & $\begin{array}{l}\text { Dairy } \\
\text { cows }\end{array}$ & $\begin{array}{l}\text { Grassland } \\
\text { animals }\end{array}$ & Pigs & Poultry & Mixed \\
\hline 2015 & 58.7 & 65.7 & 45.1 & 52.3 & 19.8 & 50.6 & 88.6 & 13.5 \\
\hline 2016 & 54.4 & 61.7 & 6.4 & 57.8 & 20.0 & 70.2 & 86.7 & 27.6 \\
\hline 2017 & 58.6 & 50.5 & 42.1 & 70.1 & 27.1 & 73.7 & 88.1 & 40.7 \\
\hline 2018 & 55.7 & 55.6 & -19.6 & 67.6 & 13.9 & 55.8 & 87.7 & 27.3 \\
\hline 2019 & 52.7 & 63.8 & 24.5 & 67.4 & 19.9 & 78.3 & 89.7 & 35.9 \\
\hline $\begin{array}{l}\text { Average level } \\
\text { during the } \\
\text { period } \\
\text { under } \\
\text { consideration }\end{array}$ & 56.0 & 60.4 & 26.1 & 64.2 & 20.2 & 68.2 & 88.3 & 29.9 \\
\hline
\end{tabular}

Source: Own study based on FADN data.

In the case of the surveyed farms run by natural persons, the development activity determined by the relation between accumulation and depreciation was differentiated depending on the agricultural type.

Table 4. Reproduction rate divided into agricultural types in the surveyed farms in 2015-2019 (average per 1 farm)

\begin{tabular}{|c|c|c|c|c|c|c|c|c|}
\hline Year & $\begin{array}{l}\text { Field } \\
\text { crops }\end{array}$ & $\begin{array}{l}\text { Horticultural } \\
\text { crops }\end{array}$ & $\begin{array}{l}\text { Permanent } \\
\text { crops }\end{array}$ & $\begin{array}{l}\text { Dairy } \\
\text { cows }\end{array}$ & $\begin{array}{c}\text { Grassland } \\
\text { animals }\end{array}$ & Pigs & Poultry & Mixed \\
\hline 2015 & 1.3 & 1.7 & 0.7 & 1.1 & 0.4 & 0.9 & 3.6 & 0.2 \\
\hline 2016 & 1.1 & 1.4 & 0.1 & 1.4 & 0.4 & 2.0 & 3.5 & 0.5 \\
\hline 2017 & 1.4 & 1.0 & 0.6 & 2.5 & 0.6 & 2.4 & 3.8 & 1.0 \\
\hline 2018 & 1.3 & 1.3 & -0.2 & 2.3 & 0.3 & 1.2 & 4.3 & 0.6 \\
\hline 2019 & 1.3 & 1.8 & 0.3 & 2.3 & 0.4 & 3.3 & 5.2 & 0.8 \\
\hline $\begin{array}{l}\text { Average level } \\
\text { during the } \\
\text { period under } \\
\text { consideration }\end{array}$ & 1.3 & 1.4 & 0.3 & 1.9 & 0.4 & 1.9 & 4.1 & 0.6 \\
\hline
\end{tabular}

Source: Own study based on FADN data. 
In light of the data presented in Table 4, by far the most favourable situation in this respect, in 2015-2019, was recorded in farms specialising in poultry, where accumulation was on average about 4 times higher than depreciation. In the case of farms with field crops, horticultural crops, dairy cows and pigs, there was also more accumulation than depreciation, but it was not as significant as in the case of poultry farms. Farms of the aforementioned agricultural types manifested an extended reproduction of fixed assets, which meant that in addition to the chances for further functioning, they also showed a developmental approach. On the other hand, in farms with mixed plant and animal production, with permanent crops and specialised in grassland animal husbandry, the level of accumulation is lower than the level of annual depreciation write-offs. Farms of these types were only capable of limited reproduction of fixed assets (fixed asset reproduction rates from 0.3 to 0.8 ). This means that these farms were not able to reproduce the value of consumed fixed assets, and even less to undertake developmental activities.

\section{Economic size and development potential of farms run by natural persons}

Recognition of development opportunities for farms run by natural persons from the FADN sample was enriched by an assessment of income, accumulation rate and reproduction rate in farms according to economic size classes. Analysing Table 5, it may be noticed that the average income from a family farm, within the period in question, is directly proportional to the economic size of agricultural holdings. In the analysed period the average level ranged from PLN 9,466 to 917,840.

Table 5. Income from the family farm divided according to economic size classes in the surveyed farms in 2015-2019 (average per 1 farm in PLN)

\begin{tabular}{|c|c|c|c|c|c|c|}
\hline Year & $\begin{array}{l}\text { Very } \\
\text { small } \\
(2<=€<8)\end{array}$ & $\begin{array}{l}\text { Small } \\
(8<=€<25)\end{array}$ & $\begin{array}{l}\text { Medium- } \\
\text { small } \\
(25<=€< \\
50)\end{array}$ & $\begin{array}{l}\text { Medium-large } \\
(50<=€< \\
100)\end{array}$ & $\begin{array}{l}\text { Large } \\
(100<=€< \\
500)\end{array}$ & $\begin{array}{l}\text { Very } \\
\text { large } \\
(€=>500)\end{array}$ \\
\hline 2015 & 8,040 & 27,228 & 61,630 & 109,049 & 251,726 & 828,446 \\
\hline 2016 & 8,604 & 27,529 & 65,821 & 123,066 & 282,814 & 775,932 \\
\hline 2017 & 9,576 & 33,376 & 84,174 & 160,648 & 343,651 & 802,644 \\
\hline 2018 & 8,061 & 30,920 & 78,780 & 148,257 & 311,198 & 822,279 \\
\hline 2019 & 11,959 & 34,860 & 83,220 & 163,222 & 371,394 & $1,395,053$ \\
\hline $\begin{array}{l}\text { Average } \\
\text { level } \\
\text { during the } \\
\text { period } \\
\text { under } \\
\text { considerati } \\
\text { on }\end{array}$ & 9,466 & 30,864 & 74,355 & 139,999 & 309,591 & 917,840 \\
\hline
\end{tabular}

Source: own study based on FADN data. 
The highest incomes were achieved by the economically strongest farms, the so-called very large farms. In the researched period, the lowest income from a family agricultural holding occurred in very small farms, i.e. farms with an economic size between EUR 2 and 8 thousand SO. Among the farms distinguished by economic size classes, between 2015 and 2019 there was a significant increase in income. A particularly strong growth in family farm income at current prices occurred in farms with an economic size of more than EUR 500 thousand SO (here, income growth between 2015 and 2019 stood at $68 \%$ ). It should be added that the highest current income in all analysed groups was recorded in 2019, while the lowest was in 2015, with the exception of very large farms, where 2016 saw the lowest family farm income in the analysed years.

The data presented in Table 6 show that in the studied holdings of natural persons separated by economic size class, in 2015-2019, there were significant differences in the accumulation rate. In very small and small farms, i.e. farms with an economic size of up to EUR 25 thousand SO, the accumulation rate, in all the years studied, was negative, and so accumulation did not occur. Consumption in this group of farms exceeded the obtained income from the family agricultural holding. On the other hand, in agricultural holdings over EUR 50 thousand, the accumulation rate ranged from $44.8 \%$ in mediumlarge agricultural holdings to $95.7 \%$ in very large agricultural holdings.

Table 6. Accumulation rate divided into economic size classes in the surveyed farms in 2015-2019 (average per 1 farm in \%)

\begin{tabular}{|l|l|l|l|l|l|l|}
\hline & $\begin{array}{l}\text { Very } \\
\text { small } \\
(2<=€<8)\end{array}$ & $\begin{array}{l}\text { Small } \\
(8<=€< \\
25)\end{array}$ & $\begin{array}{l}\text { Medium- } \\
\text { Small } \\
(25<=€< \\
50)\end{array}$ & $\begin{array}{l}\text { Medium- } \\
\text { large } \\
(50<=€< \\
100)\end{array}$ & $\begin{array}{l}\text { Large } \\
(100<=€< \\
500)\end{array}$ & $\begin{array}{l}\text { Very } \\
\text { large } \\
(€=>500)\end{array}$ \\
\hline 2015 & -345.2 & -37.3 & 35.8 & 62.0 & 83.7 & 95.8 \\
\hline 2016 & -315.8 & -36.6 & 39.1 & 65.8 & 85.2 & 95.0 \\
\hline 2017 & -285.9 & -15.0 & 51.0 & 73.0 & 87.4 & 94.9 \\
\hline 2018 & -371.8 & -26.6 & 46.7 & 70.2 & 85.7 & 94.8 \\
\hline 2019 & -223.3 & -15.8 & 48.5 & 72.1 & 87.6 & 96.9 \\
\hline $\begin{array}{l}\text { Average level } \\
\text { during the } \\
\text { period } \\
\text { under } \\
\text { consideration }\end{array}$ & -294.3 & -25.1 & 44.8 & 69.1 & 86.0 & 95.7 \\
\hline
\end{tabular}

Source: own study based on FADN data.

It was observed, that as the economic size rises, so too does the reproduction rate (Table 7). Farms with an economic size of up to EUR 25 thousand SO, in the examined period, recorded a negative reproduction rate, which indicates a lack of development opportunities or even the possibility to reproduce fixed assets. It can be concluded that the functioning of these farms is possible due to the income obtained from outside the 
agricultural holding ${ }^{13}$ (Kambo, Juchniewicz and Michalak, 2020). In the group of medium-small farms, i.e. with an economic size of EUR 25 to 30 thousand, there was simple reproduction (1), which indicates a chance for further functioning and manifests itself in the possibility to reproduce farm assets. However, there are no development opportunities in this group of farms. In the remaining economic size classes, i.e. above EUR 50 thousand SO, there was extended reproduction (1.8 - 3.3). Definitely, the most favourable situation was observed in very large farms (above EUR 500 thousand SO), where the estimated accumulation, on average in the examined period, was more than 3 times higher than depreciation. However, in 2019, the reproduction rate here reached 5.7. Medium-large, large and especially very large holdings were not only able to reproduce fixed assets, but also showed great development potential.

Table 7. Reproduction rate divided according to economic size classes in the surveyed farms in 2015-2019 (average per 1 farm)

\begin{tabular}{|l|l|l|l|l|l|l|}
\hline Year & $\begin{array}{l}\text { Very small } \\
(2<=€<8)\end{array}$ & $\begin{array}{l}\text { Small } \\
(8<=€< \\
25)\end{array}$ & $\begin{array}{l}\text { Medium- } \\
\text { small } \\
(25<=€< \\
50)\end{array}$ & $\begin{array}{l}\text { Medium- } \\
\text { large } \\
(50<=€< \\
100)\end{array}$ & $\begin{array}{l}\text { Large } \\
(100<=€< \\
500)\end{array}$ & $\begin{array}{l}\text { Very } \\
\text { large } \\
(€=>500)\end{array}$ \\
\hline 2015 & -3.0 & -0.6 & 0.7 & 1.2 & 2.0 & 3.2 \\
\hline 2016 & -3.1 & -0.6 & 0.8 & 1.5 & 2.3 & 2.7 \\
\hline 2017 & -2.7 & -0.3 & 1.3 & 2.2 & 3.0 & 2.7 \\
\hline 2018 & -2.8 & -0.4 & 1.1 & 1.9 & 2.6 & 2.8 \\
\hline 2019 & -2.5 & -0.3 & 1.2 & 2.2 & 3.1 & 5.7 \\
\hline $\begin{array}{l}\text { Average } \\
\text { level in the } \\
\text { period } \\
\text { under } \\
\text { consideration }\end{array}$ & -2.8 & -0.4 & 1.0 & 1.8 & 2.6 & 3.3 \\
\hline
\end{tabular}

\section{Summary}

The research reveals a differentiation in the development potential of natural persons' farms depending on the agricultural type and economic size class. With respect to agricultural types, the highest average value of accumulation in relation to income from a family farm as well as the highest reproduction rate (4.1) was recorded in farms specialising in poultry farming. Thus, hypothesis two was positively verified. In farms with field crops, horticultural crops, dairy cows and pigs, there was also more accumulation than depreciation, but it was not as significant as in the case of poultry farms. Farms of the aforementioned agricultural types provided an extended reproduction of fixed assets, which meant that in addition to the capacity for further functioning, they also demonstrated a developmental approach. On the other hand, in farms with mixed plant and animal production, with permanent crops and specialised in

${ }^{13}$ Kambo K., Juchniewicz M., Michalak P.: Poziom i struktura dochodów rodzin rolników w gospodarstwach prowadzących rachunkowość w 2018 roku, Wydawnictwo IERiGŻ-PIB, Warszawa 2020. 
grassland animal husbandry, there was a narrower reproduction of fixed assets, which indicates that these farms were not able to recreate the value of consumed fixed assets, and even less likely to undertake developmental activities.

The analysis of agricultural holdings of natural persons showed that the accumulation rate and the reproduction rate increased with the economic size of agricultural holdings, which means that the first hypothesis was confirmed.

Farms with an economic size of up to EUR 25 thousand SO, in the examined period, recorded a negative accumulation rate and reproduction rate, which indicates the lack of development opportunities, or even the possibility of reproducing fixed assets. In the group of farms with an economic size of EUR 25 to 50 thousand, the reproduction rate was equal to 1 , which indicates a chance for further functioning, without development opportunities. On the other hand, in the economic size classes above EUR 50 thousand SO featured extended reproduction. Farms in this group were not only able to reproduce fixed assets, but they also show great development opportunities.

\section{References}

Goraj L., Mańko S.: Rachunkowość i analiza ekonomiczna w indywidualnym gospodarstwie rolnym, Wydawnictwo Difin, Warszawa 2009.

Grzelak A.: Akumulacja majątku w gospodarstwach rolnych w Polsce ze względu na typy produkcyjne i kontekst paradygmatu rozwoju zrównoważonego, Zagadnienia Ekonomiki Rolnej / Problems of Agricultural Economics, 3 (360), Wydawnictwo IERiGŻ-PIB, Warszawa 2019, p. 90 91.

Grzelak A.: Ocena procesów reprodukcji majątku gospodarstw rolnych prowadzących rachunkowość rolną (FADN), Zagadnienia Ekonomiki Rolnej / Zagadnienia Ekonomiki Rolnej, 3 (340), Wydawnictwo IERiGŻ-PIB, Warszawa 2014, pp. 45-51.

Józwiak W.: Strategie postępowania posiadaczy gospodarstwach rolnych i ich pozarolnicze formy aktywności gospodarczej w latach 1996-2002, Roczniki Naukowe SERiA, 6 (3), 2004, pp. 94100.

Kambo K., Juchniewicz M., Michalak P.: Poziom i struktura dochodów rodzin rolników w gospodarstwach prowadzących rachunkowość w 2018 roku, Wydawnictwo IERiGŻ-PIB, Warszawa 2020.

Kata R.: Wewnątrzsektorowe nierówności dochodów gospodarstw rolniczych w Polsce w latach 2004-2017, Nierówności społeczne a wzrost gospodarczy, 61, Wydawnictwo Uniwersytetu Rzeszowskiego, Rzeszów 2020, pp. 26-27.

Kryszak Ł., Czyżewski B.: Determinanty dochodów rolniczych. Warszawa: Wydawnictwo CeDeWu, Warszawa 2020, p. 9.

Poczta W.: Instrumenty wsparcia ekonomicznego dla rodzinnych gospodarstw rolnych w polityce strukturalnej UE i w ramach interwencjonizmu państwowego oraz rola i znaczenie tych instrumentów. In: M. Podstawka (eds.), Ekonomiczne i prawne mechanizmy wspierania i ochrony rolnictwa rodzinnego, KSOW, Warszawa 2015, pp. 142-159.

Ryś-Jurek R.: Zachowanie finansowe gospodarstw rolnych, Handel wewnętrzny, 4 (363), 2016, pp. 242-245.

Sobczyński T.: Ocena możliwości rozwojowych gospodarstw rolniczych Unii Europejskiej na podstawie inwestycji netto w latach 1998-2008, Folia Pomeranae Universitatis Technologiae Stetinesis, Oeconomica, 291 (65), 2011, pp. 145-156.

Sobczyński T.: Wpływ wielkości ekonomicznej gospodarstw rolniczych UE na ich możliwości rozwojowe. Zeszyty Naukowe SGGW w Warszawie. Problemy Rolnictwa Światowego, 9 (24), Warszawa 2009, pp. 161-162. 
Wiatrak A. P.: Współzależność akumulacji i spożycia w gospodarstwach i rodzinach chłopskich, Wieś i rolnictwo, 1 (22), 1979, p. 163.

Wiatrak A. P.: Uwarunkowania akumulacji w gospodarstwach rodzinnych w rolnictwie, Wieś i rolnictwo, 4 (57), 1987, p. 25.

\section{Możliwości rozwojowe gospodarstw rolnych w Polsce}

\section{Streszczenie}

Głównym celem opracowania jest rozpoznanie i ocena możliwości rozwojowych wśród gospodarstw rolnych w Polsce ze względu na typy rolnicze i klasy wielkości ekonomicznej. Zakres czasowy opracowania odnosi się do lat 2015-2019 i dotyczy wyników gospodarstw rolnych osób fizycznych prowadzących rachunkowość rolną w ramach Polskiego FADN. Cel opracowania został zrealizowany poprzez ocenę poziomu dochodu $\mathrm{z}$ rodzinnego gospodarstwa rolnego, akumulacji i reprodukcji w badanych gospodarstwach rolnych. Z przeprowadzanych badań wynika, iż wystąpiło zróżnicowanie możliwości rozwojowych gospodarstw osób fizycznych w zależności od typu rolniczego i klasy wielkości ekonomicznej. W gospodarstwach z drobiem odnotowano najwyższą średnią wartość akumulacji w stosunku do dochodu $\mathrm{z}$ rodzinnego gospodarstwa rolnego, jak również najwyższy wskaźnik reprodukcji. W gospodarstwach z uprawami polowymi, ogrodniczymi, krowami mlecznymi i trzodą chlewną również wystąpiła przewaga akumulacji nad amortyzacją i gospodarstwa te zapewniały rozszerzoną reprodukcję majątku trwałego. $\mathrm{Z}$ kolei $\mathrm{w}$ gospodarstwach $\mathrm{z}$ mieszaną produkcją roślinną $\mathrm{i}$ zwierzęcą, $\mathrm{z}$ uprawami trwałymi oraz wyspecjalizowanych $\mathrm{w}$ chowie zwierząt trawożernych miała miejsce zawężona reprodukcja majątku trwałego.

Analiza gospodarstw rolnych osób fizycznych wykazała, że stopa akumulacji i wskaźnik reprodukcji rosły wraz ze wzrostem wielkością ekonomiczną gospodarstw rolnych. Gospodarstwa o wielkości ekonomicznej do 25 tys. euro SO w badanym okresie odnotowały stopę akumulacji i wskaźnik reprodukcji mniejsze od zera. W grupie gospodarstw o wielkości ekonomicznej od 25 do 50 tys. euro, wskaźnik reprodukcji był równy 1. Natomiast w klasach wielkości ekonomicznej powyżej 50 tys. euro SO miała miejsce reprodukcja rozszerzona.

Slowa kluczowe: amortyzacja, akumulacja, gospodarstwo rolne.

Kody JEL: Q12, Q14, D25.

Information about the author:

Mgr. Monika Juchniewicz

Institute of Agricultural and Food Economics - National Research Institute

Świętokrzyska 20, 00-002 Warszawa

e-mail: monika.juchniewicz@ierigz.waw.pl

ORCID: 0000-0003-3016-1430

Mgr. Lukasz Podstawka

Warsaw University of Life Sciences

Nowoursynowska 166, 02-787 Warszawa

e-mail: lukasz_podstawka@sggw.pl

ORCID: 0000-0002-7394-0218 